\title{
An Analytic View of the Selected Methods of Performance Evaluation in Slovak Business Entities
}

\author{
Jana Cocul'ová \\ Faculty of Management, University of Prešov in Prešov, Faculty of Management, SK.
}

\begin{abstract}
Performance evaluation as one of the basic features of human resource management is an important tool for stimulating employees so they can achieve the pre-set goals and improve the performance of the whole business entity. The choice of the right performance evaluation method should take into account a number of criteria the fulfillment of which is a prerequisite for their acceptance by entity's employees. The paper deals with the comparison of selected methods from the standpoint of its perception by evaluated employees. The paper also presents results of the research conducted in Slovak business entities. Moreover, the research's aim was to determine statistically significant differences between selected performance evaluation methods in terms of perception of selected criteria like objectivity, validity, the incentive effect, the impact on remuneration and career progression. For this purpose the research tested 5 statistical hypothesis using Skillings-Macs test to test multiple measurements and the post-hoc test.
\end{abstract}

Keywords: Human resource management; Human resource management activity; Performance evaluation; Performance evaluation method.

\section{INTRODUCTION}

Human capital with its knowledge, skills and abilities becomes a critical factor for economic success of organizations [1]. The issue of performance appraisal is becoming more and more the main focus of attention on both the academic and practical level. Performance appraisal used to be regarded a marginal responsibility of the line manager, whose duty was to perform an annual report on the performance of employees [2]. Performance appraisal was once considered a process involving a line manager simply completing an annual report on subordinate's performance, but as time passed, it has become an integral part of the performance management system and performance appraisal is today considered the key element of performance management [3]. Human capital with its knowledge, skills and abilities becomes a critical factor for economic success of organizations [1]. The issue of performance appraisal is becoming more and more the main focus of attention on both the academic and practical level. Performance appraisal used to be regarded a marginal responsibility of the line manager, whose duty was to perform an annual report on the performance of employees [2]. Performance appraisal was once considered a process involving a line manager simply completing an annual report on subordinate's performance, but as time passed, it has become an integral part of the performance management system and performance appraisal is today considered the key element of performance management [3].

\section{LITERATURE REVIEW}

Employee performance appraisal has been practiced by numerous organizations since centuries. Though performance appraisal system has been debated by many, however, overall, it is viewed that performance appraisal is an inseparable part of organizational life [4].The modern approach to employee appraisal represents a standardised procedure for detection, 
assessment and adjustment efforts, including the setting of objectives and targets, which affect the employee performance appraisal. Armstrong [5] describes performance management as a strategic and integrated approach to delivering sustained success to organizations by improving the performance of the people who work in them and by developing the capability of teams and individual contributors. Fletcher [6] further defines performance appraisal as an umbrella term for a variety of activities through which organizations seek to assess employees and develop their competences, enhance their performance and distribute rewards.

The purpose of employee performance appraisal is not only to recognize the current level of performance of a worker, but also to recognize their strengths and weaknesses, to create a basis for employee remuneration according to their achievements, to motivate employees to improve their performance, to recognize the needs in education and development, to recognize the worker's potential (and their limits), to create a basis for planning of needs of employees and identifying the future work tasks, etc. [7]. Performance management at the individual level consists of the synchronization of work of each employee with the strategic plan of the organization, so that the efforts of an employee are oriented on the products and processes which contribute to the success of the organization as a whole [8].

Numerous authors have previously paid attention to the performance appraisal. According to Armstrong [5], performance appraisal may be seen as a top-down after-the-fact form of appraising subordinates for the purposes of obtaining information on which to base decisions on wages. Performance management, however, is a continual cycle of performance planning, design and/or redesign of structures, managing performance and reviewing the performance. Performance appraisal is one of the intensely researched topics in the field of industrial/organizational psychology [8]. It is a formal process of employee monitoring and usually involves evaluating performance based on the judgments and opinions of subordinates, peers, supervisors, other managers and even workers themselves [9]. Similarly, performance appraisal has been defined as activities through which organizations seek to assess employees and develop their competences, enhance performance and distribute rewards [3].

Performance appraisal is defined as evaluating an employee's current or past performance relative to his or her performance standards. The appraisal process therefore involves [10]:

- Setting work standards;

- Assessing the employee's current performance relative to these standards;

- Providing employee with feedback with the aim of motivating the worker in order to eliminate performance deficiencies or to continue to perform highly.

Lansbury [11] suggests that performance appraisal is the process of identifying, evaluating and developing work performance of employees in the organization, so that the organizational goals and objectives are more effectively achieved, while at the same time aiding employees in order to feel recognition, receive feedback, feel resposible for work and get career guidance.

Generally, organizations use performance appraisals for evaluation and developmental purposes. Performance appraisal acts first of all as a basis for the improvement of human resources [12]. It is reflected on renumeration, hiring of new employees, training and development of current employees, restructuring workflow and on employee motivation. It may also help identify the strengths and weaknesses, to assess training needs and to identify the potentials for promotion. 
Performance evaluation is a formal (official) evaluation of individual's work performance. It also informs employees on how their performance is evaluated and whether it is possible to improve their performance and identify ways it can be improved [13]. Peterson [14] claims that performance evaluation is a tool used by managers and human resources departments to examine employee performance within a set time period. Often it includes details of productivity, attitude, accuracy and ability to meet the set objectives. Performance evaluation can also have a positive impact on all aspects of business. If performance evaluation is to develop employees and help with their performance, it should meet the following requirements [15]:

1. objectivity,

2. versatility,

3. comparability,

4. systematic and thorough preparation,

5. two-way approach/ multi-way approach,

6. focus on the present,

7. focus on the performance,

8. emphasis on the positive aspects,

9. up-to-date nature of the evaluation.

After selecting the evaluation method the determination of monitoring, recording and evaluation procedures should follow. To that end, many methods of evaluation were established in order to eliminate the common problems the process entails. The method involves evaluation, processing and recording of results. However, no method is perfect [12].

Currently, the performance evaluation systems continuously evolve and are becoming more efficient. Instead of focusing on the past, potential flaws and weaknesses of employees' performance evaluators tent to focus more on the future by encouraging employees and proposing solutions to already existing problems. A vital factor is also an interview with an employee where a boss tries to elicit solution from an employee so he/ she will also become active in achieving the set goals. Employees then cease to play a passive role and become active participants in the performance evaluation. There is thus a shift from "grading" to the problem solving, and the shift from the paper evaluation to the "face to face" evaluation [8].

\section{METHODOLOGY}

In order for the performance evaluation to be efficient and lead to an increase in performance (that is why evaluations are being carried out) it has to be accepted by an employee. Employees should have a feeling that the performance evaluation is set correctly, i.e. must meet the minimum criteria such as objectivity, fairness, motivation. Given that different business entities use different methods of performance evaluation, the aim of the research was to assess the perception of various performance evaluation methods. The research was conducted on a sample of 83 respondents. Data was collected using a standardized questionnaire which was distributed to respondents in person or electronically.

The aim of the research was to find out statistically significant differences in the perception of selected performance evaluation methods. For the sake of the research were selected seven performance evaluation methods. However, given the low number of responses for certain methods (assessment centers, BARS) there were processed results only for five performance evaluation methods, as follows:

1. Assess compliance with set objectives (M1).

2. Free description (M2). 
3. Rating scale (M3).

4. Assessment interview (M4).

5. 360 degree feedback (M5).

Each method was assessed using five selected criteria, on a scale from 1 to 5 ( 1 is for a minimal value, 5 is the maximum level of implementation of the criterion):

1. Objectivity.

2. Validity.

3. Motivation.

4. Impact on remuneration.

5. Impact on career.

There were tested 5 statistical hypotheses using Skillings-Mack to test multiple measurements and post-hoc test tests at a significance level of $5 \%$.

\section{RESULTS OF RESEARCH}

H1: There are significant differences in the perception of the objectivity between the performance evaluation methods.

The first criterion, which was the subject of the comparison, was the objectivity. The result of the statistical analysis showed that there are statistically significant differences between the performance evaluation methods, mainly in the perception of their objectivity, see Table 1.

Table 1. Testing the hypothesis H1 using Skillings-Mack test to test multiple measurements.

\begin{tabular}{ll}
\hline Criterion & Objectivity \\
\hline Dev & 3488.4 \\
SM & 14.18 \\
p test value & $\mathbf{0 . 0 0 7}$ \\
\hline
\end{tabular}

Table 2 shows the value of post-hoc test which aim was to find out the most significant differences between pairs of performance evaluation methods.

Table 2. The results of post-hoc test for the hypothesis $\mathrm{H1}$.

\begin{tabular}{llllll}
\hline Objectivity & & & & \\
\hline & M1 & M2 & M3 & M4 & M5 \\
M1 & 0.0 & 1.5 & -25.5 & -27.5 & 20.0 \\
M2 & & 0 & -27 & -29 & 18.5 \\
M3 & & 0 & -2 & $\mathbf{4 5 . 5}$ \\
M4 & & & 0 & $\mathbf{4 7 . 5}$ \\
M5 & & & & & 0 \\
\hline
\end{tabular}

With regard to the results of statistical tests, it was found that in terms of objectivity two pairs of performance evaluation methods significantly differ, namely the methods of rating scale (M3) and 360 degree feedback (M5), as well as the assessment interview (M4) and 360 degree feedback (M5). In terms of the perception of these methods by respondents the method of grading scale and assessment interview were perceived as the most objective evaluation methods in comparison with other methods. The least objective method is perceived to be the method of 360 degrees feedback. This is a surprising finding given that this method is based on an independent evaluation of several persons who are in contact with an evaluated person, 
including his/ her co-workers or subordinates. It could be stated that the assessment made by certain individuals (such as co-workers or subordinates) is not perceived as sufficiently objective.

H2: There are significant differences in the perception of the validity between the performance evaluation methods.

Other criterion that was examined was labeled as "validity", meaning whether the persons evaluated see the evaluation method used as a proper tool (whether the evaluated aspects are those which should really be evaluated). Table 3 shows the results of Skillings-Macs test which aim was to find out the most statistically significant differences in terms of validity.

Table. 3 Testing the hypothesis $\mathrm{H} 2$ using Skillings-Mack test to test multiple measurements.

\begin{tabular}{lcc}
\hline Criterion & Validity \\
\hline Dev & \multicolumn{2}{c}{7662.4} \\
SM & 25.38 & \\
p test value & $\mathbf{0 . 0 0 0}$ & \\
\hline
\end{tabular}

The more detailed data analysis used post-hoc test; the results shown in Table 4.

Table. 4 The results of post-hoc test for the hypothesis $\mathrm{H} 2$.

\begin{tabular}{lllcll}
\hline Validity & & & & \\
\hline & M1 & M2 & M3 & M4 & M5 \\
M1 & 0 & -1 & -33 & -66.5 & 0.5 \\
M2 & 0 & -32 & -65.5 & 1.5 \\
M3 & & 0 & -33.5 & 33.5 \\
M4 & & & 0 & $\mathbf{6 7}$ \\
M5 & & & & 0 \\
\hline
\end{tabular}

According to the result of post-hoc test, statistically significant differences were found in three methods evaluated, specifically between the method of the assessment of the compliance with set objectives (M1) and the method of assessment interview (M4). In this case it was found that the assessment of the compliance with set objectives was perceived as a less valid method than the method of assessment interview. Similar results were achieved in the case of the method of free description (M2), which was in terms of validity seen as less positive than the assessment interview method (M4). We assume that the reason for this is the fact that while the method of the assessment of the compliance with set objectives and free description usually cannot be influenced by the person being evaluated, the method of assessment interview provides an opportunity for a feedback and also gives a chance to the person evaluated to point out important factors influencing the evaluation process. The statistical difference was confirmed also in case of the pair of methods assessment interview and 360 degree feedback.

H3: There are significant differences in the perception of motivation between the performance evaluation methods.

The third criterion is motivation, meaning whether the outcome of a properly used evaluation method has an incentive effect on an employee, like higher working efficiency in the next reporting period. If an evaluation method does not fulfill this aspect, it cannot be considered as sufficiently effective. Significant differences were found for this criterion as well, see Table 5. 
Table. 5 Testing the hypothesis H3 using Skillings-Mack test to test multiple measurements.

\begin{tabular}{ll}
\hline Criterion & Motivation \\
\hline Dev & 17013.5 \\
SM & 53.37 \\
p test value & $\mathbf{0 . 0 0 0}$ \\
\hline
\end{tabular}

The results of post-hoc test to determine pairs of methods between which were found statistically significant differences are shown in Table 6.

Table. 6 The results of post-hoc for the hypothesis $\mathrm{H} 3$.

\begin{tabular}{llllll}
\hline Motivation & & & & \\
\hline & M1 & M2 & M3 & M4 & M5 \\
M1 & 0 & $\mathbf{5 9 . 5}$ & -27 & $-\mathbf{5 8}$ & 3 \\
M2 & 0 & -86.5 & -117.5 & -56.5 \\
M3 & & 0 & -31 & 30 \\
M4 & & & 0 & $\mathbf{6 1}$ \\
M5 & & & & & 0 \\
\hline
\end{tabular}

For the method of free description (M2) were found statistically significant differences in all the other methods, and this method was perceived as the least motivating for future job performance. It can be concluded that this method does not set future goals and objectives to be met by employees. Therefore, the method does not fulfill its essential purpose - stimulate employees to perform better at their tasks. The method of assessment interview (M4) was perceived more positively in terms of an incentive effect in comparison with the evaluation methods of set objectives (M1) and 360 degree feedback (M5).

H4: There are significant differences in the perception of the impact of evaluation on employees' remuneration between the performance evaluation methods.

The research took into account also the impact on the remuneration of employees. It is obvious that if the outcome of the evaluation is not reflected in the remuneration of employees, such an evaluation would not have the desired effect.

As shown in Table 7, this criterion also showed statistical differences.

Table. 7 Testing the hypothesis $\mathrm{H} 4$ using Skillings-Mack test to test multiple measurements,

\begin{tabular}{ll}
\hline Criterion: & Remuneration \\
\hline Dev & 8843.3 \\
SM & 42.85 \\
p test value & $\mathbf{0 . 0 0 0}$ \\
\hline
\end{tabular}

Using the post-hoc test, statistical differences were found in the case of the method 360 degree feedback, see Table 8. 
Table. 8 Results of the post-hoc test for the hypothesis $\mathrm{H4}$,

\begin{tabular}{lccccl}
\hline Remuneration & & & & \\
\hline & M1 & M2 & M3 & M4 & M5 \\
M1 & 0 & -12 & -34 & -39.5 & $\mathbf{4 0 . 5}$ \\
M2 & & 0 & -22 & -27.5 & $\mathbf{5 2 . 5}$ \\
M3 & & 0 & -5.5 & $\mathbf{7 4 . 5}$ \\
M4 & & & 0 & $\mathbf{8 0}$ \\
M5 & & & & & 0 \\
\hline
\end{tabular}

The results of the tests confirm that the method 360 degree feedback (M5) has in terms of its perception by employees lower impact than other methods that have been investigated. It is obvious that this method, even though it is used in Slovak organizations only rarely, is just a supplementary tool and its results are not seen as sufficient enough to be reflected in employees' pay.

H5: There are significant differences in the perception of the impact of performance evaluation methods on the career progression between the performance evaluation methods

A very important criterion that should be respected in the evaluation of the business entity's performance is the impact on employees' career development. Performance evaluation should be one of the tools of a career management. Career progression should depend on previous job performance, so it is important to include this aspect into the appraisal system. Results of tests confirmed the hypothesis H5, see Table 9.

Table. 9 Testing the hypothesis H5 using Skillings-Mack test to test multiple measurements.

\begin{tabular}{ll}
\hline Criterion & Career progression \\
\hline Dev & 6815.4 \\
SM & 24.77 \\
p test value & $\mathbf{0 . 0 0 0}$ \\
\hline
\end{tabular}

Using the post-hoc test, statistical differences were found in the case of the method meeting the objectives, see Table 10.

Table. 10 Results of the post-hoc test for the hypothesis H5.

\begin{tabular}{|c|c|c|c|c|c|}
\hline \multicolumn{6}{|c|}{$\begin{array}{l}\text { Career } \\
\text { progression }\end{array}$} \\
\hline & M1 & M2 & M3 & M4 & M5 \\
\hline M1 & 0 & 56 & 46.5 & 54 & 73.5 \\
\hline M2 & & 0 & -9.5 & -2 & 17.5 \\
\hline M3 & & & 0 & 7.5 & 27 \\
\hline M4 & & & & 0 & 19.5 \\
\hline M5 & & & & & 0 \\
\hline
\end{tabular}

The test results have pointed out to the fact that the method of the evaluation of set objectives is linked to the career progression far more strongly than the method of free description, assessment interview and 360 degrees feedback. It is evident that the method which clearly defines and measures objectives employees are to meet is the right method to determine the career progression in the given business entity. 


\section{CONCLUSION}

Performance evaluation of employees is an important part of effective human resources management. Performance evaluation constitutes an important instrument for influencing the performance of employees. In order for the performance evaluation to meet its purpose, it must have a properly set methodology which will be fully accepted by employees. It is therefore very important to choose the right performance evaluation method that will fulfill the essential criteria, as seen by employees, such as objectivity, validity, the incentive effect, the impact on remuneration, career progression.

This research confirmed that performance evaluation methods are perceived by employees very differently. The research results show that employees perceive the method of the assessment interview to be the most positive from among all the other evaluated methods. The contact between the evaluator and evaluated employee is the crucial factor since it provides the opportunity to leave a feedback or explain in detail circumstances that had occurred before the evaluation took place. This direct contact makes it possible for the evaluated employee to rate the performance evaluation method. Obviously, this aspect contributes to the positive perception of the performance evaluation method. The research results showed that the least popular method of performance evaluation is 360 degrees feedback method. This finding is very interesting because this method is a very modern and innovative approach to the evaluation of job performance based on the evaluation given by several independent persons, like a supervisor, co-workers or subordinates, creating thus ensuring high objectivity. But it is clear that this method has not been widely accepted in Slovak business entities. The research brought up very up-to-date information on the performance evaluation methods and showed the need for further research in this field.

\section{References}

1. Ali Taha, V., M. Sirková, and M. Ferencová, Selected practices of talent management insight into Slovak organizations. Polish Journal of Management Studies, 2013. 8(1): p. 16-25

2. Cocul'ová, J., and N. Svetozárovová, Analysis of employees performance evaluation in the stage of globalization, in Proceedings: Globalization and its socio-economic consequences, 2015, Žilina, Žilinská univerzita. P: 731-735.

3. Del Po, A., The Performance Appraisal Handbook: Legal \& Practical Rules for Managers, 2th edition 2007. Nolo. 224.

4. Islam, R., and S.M. Rasad, Employee Performance Evaluation by AHP: Case Study, in Proceedings: dISAHP 2005, Honolulu, Hawaii, 2005. P: 1-16.

5. Armstrong, M., Řízení lidských zdrojů, 2002. Praha: Grada Publishing. 800.

6. Fletcher, C. Performance appraisal and management: the developing research agenda. Journal of Occupational and Organizational Psychology, 2001. 74(8): p.473-487.

7. Hroník, F., Hodnocení pracovníků, 2006. Praha: Grada Publishing. 126.

8. Babel’ová, Z., Faktory ovplyvňujúce spokojnost' a výkonnost' zamestnancov. Acta Universitatis Matthiae Belii, 2012. 16(1): p. 41-45.

9. Koubek, J., Řízení lidských zdrojů, 2001. Praha: Management Press. 400.

10. Byars, L.L., and W.L. Rue, Human resource management, 1997. Boston, Irwin: McGraw-Hill. 432.

11. Lansbury, R., Performance Management: A Process Approach. Human Resource Management, 1988. Australia, p: 46-55.

12. Kachaňáková, A., Personálny manažment, 2011. Bratislava: Iura Edition, s.r.o. 235.

13. Donelly, J.H., J.L. Gibson, and J.M. Ivanchevich, J. M. Management, 1997. Praha: Grada Publishing. 824. 
Coculova, J. (2016). An Analytic view of the Selected Methds of Performance Evaluation in Slvak Business Entities. Advances in Social Sciences Research Journal, 3(13) 18-26.

14. Peterson, J., Employee Evaluation Definition, 2014. available on:

15. www.ehow.com/about-6708466-employee-evaluation-definition.html.

16. Repková, K., Personálna práca v organizácii, 1999. Bratislava: Miroslav Mračko. 176.

17. This work was supported under Grant VEGA 1/0513/14 „Výskum možnosti merania a hodnotenia vplyvu praktík riadenia l'udských zdrojov na výkonnost' organizácie“ 